\title{
The Practice of Red Culture on Party Spirit Education for Undergraduate Party Members
}

\author{
Lin Qu \\ Tianjin University of Finance and Economics, Tianjin, China.
}

Keywords: red culture; Party Spirit Education; practice

\begin{abstract}
As an important part of socialist core value system, red culture has specific historical connotation and education functions. Under the background of building a culturally strong country, it is of great significance to integrate red culture into the education of Party Spirit among undergraduate party members.
\end{abstract}

\section{The Foundation of the Integration of Red culture and the Practice of Party Spirit Education}

Red culture is an advanced culture with Chinese characteristics led by the Chinese Communists in the process of revolutionary war and social construction. The red culture is guided by Marx's theory and is the product of the integration of Marx's guiding ideology with China's concrete reality. The red culture originated from the revolutionary period, and it is an important manifestation of the revolutionary spirit of the Chinese nation and the profound historical and cultural connotation. Although its core connotation, such as seeking truth and pragmatism, hard struggle, selfless dedication and firm belief, is still in conformity with the education of socialist core values and the construction of socialist spiritual civilization, it is a new carrier of the theory of Marx's doctrine in the new era.

\section{The Significance of the Integration of Red Culture and Party Spirit Education Practice}

The red culture contains the deeds of the revolutionary forerunners of the revolutionary forerunners, which contain the spirit of patriotism that the Communists are not afraid of hardships and hardships, unity and liberation, and emancipated by the independence of the nation. It embodies the Chinese Communists in the pursuit of revolutionary truth, the reality of national independence and the building of a strong country. The spirit of revolution and the fine style of work. These spirit and style are lack of college students and necessary for college students' Ideological and political education. Therefore, it is necessary to strengthen the education of red culture in college students. Through excavating the educational practice function of red culture, it points out the direction for the innovation and development of the ideological and political education of College students in the new period, especially in Colleges and universities. It is of great significance to integrate the red culture education into the party spirit education of the student party members, and make it take the initiative to play the initiative of the party members to guide the university students to strengthen their ideals and beliefs and strengthen their ideological and political qualities.

Firstly, it will strengthen the party's education and deepen the ideological and political education.

The present group of college students is growing in a new and fast changing period. Student party members in colleges and universities also have problems such as having a smattering of knowledge, not fully joining the party in ideology, deep understanding of theory, and incomplete understanding of history. The integration is good for teaching the systematic education of Marx, Mao Zedong and socialism with Chinese characteristics for college students, which will improve their ideological and moral quality and evaluation and selection ability, and will good for cultivate qualified builders and successors of the cause of social justice.

Secondly, it will enrich the content of party spirit education, and actively activate the party spirit education form.

The integration of red cultural material and spiritual resources into the party education of college 
student party members can provide rich field material and fresh education cases, and enrich the specific content of the party education in many aspects and angles. It will help the student party members to understand the meaning of the ideal and belief in a more thorough and comprehensive way, to learn the way to guide the college students, to mobilize the demonstration enthusiasm and the initiative of the party members, and to enhance the pertinence and practicality of the party education of the party members of the college students.

\section{The Present Situation and Existing Problems of the Integration}

Firstly, the red education practice is not systematic, providing less practical platform. For the learning of red culture, college student party members are very lacking in initiative. They more rely on the guidance of education in universities. However, although colleges and universities have recognized the important significance of the red culture and education practice, they lack unified leadership and specific guidance on the integration of red culture into the party education work, and have not yet established the coordination of various departments. Although the teaching contents of red culture are integrated into the ideological and political class and the party class, there is still a lack of scientific and rigorous teaching objectives and teaching plans. The theoretical and practical teaching is disjointed, and the systematic education system has not been formed, and the effect of education is poor.

Secondly, the educational means are not rich enough, and the effect of education needs to be improved. As the main position to propagate and disseminate the ideological and political education value of the red culture, colleges and universities are faced more and more students who are born after 1995, active in thinking, distinct in personality, dare to try and love new things. Therefore, the law of growth of college students should be followed in the course of red culture education and the law of College Students' growth. Appeal, pragmatic education content, innovative education methods, with students' favorite educational means to enhance the attractiveness and appeal of education. But at present, in the development of red culture education, the lack of new top-level design and rich means do not reflect the spirit of keeping pace with the times, and the means of education need to be rich and innovative.

Thirdly, the party spirit education emphasizes form rather than content feedback and evaluation mechanism.

At present, the red culture education in Colleges and universities is lacking a clear requirement for the students' learning effect. There are more unidirectional professors, less feedback and less study on the learning effect of the student party members. This will cause the students despise the party education and study, take the form and only for the purpose of completing the task instead of achieving deep thinking and actively exploring practical learning effects. On the other hand, the practice activities of red culture education in Colleges and universities are lack of clear purpose and specific goals. The spiritual connotation of red culture is not deeply studied and excavated, and the design of the program is not rigorous and characteristic, which leads the red culture practice only shouting slogans and less attractive to the educated. At present, the red culture education in Colleges and universities is lacking a clear requirement for the students' learning effect. There are more unidirectional professors, less feedback and less study on the learning effect of the student party members. This will cause the students despise the party education and study, take the form and only for the purpose of completing the task instead of achieving deep thinking and actively exploring practical learning effects. On the other hand, the practice activities of red culture education in Colleges and universities are lack of clear purpose and specific goals. The spiritual connotation of red culture is not deeply studied and excavated, and the design of the program is not rigorous and characteristic, which leads the red culture practice only shouting slogans and less attractive to the educated. The practical process of practice is mostly a simple and simple visit or oath, lacking in ritual and deep understanding, so that the spiritual connotation of the red spirit has not been embodied in the spiritual baptism of the students. With the end of practice, the content of practice is forgotten, and the relevant materials of educational practice are hard to be applied to teaching and scientific research again, without achieving an orderly cycle. 


\section{Countermeasures and Suggestions on the Integration}

Firstly, create a good atmosphere for carrying forward the red culture.

The integration of red culture into the party education for college student party members is of great significance. It is necessary to strengthen the publicity and promotion of red culture and create a good atmosphere for carrying forward the red culture. On the one hand, we should make full use of campus radio, school newspaper, school bulletin and window, display red stories, play red songs, disseminated red poems, and use the new media platforms such as micro-blog, We Chat, young voice, super campus and other new media platforms to publicize and carry forward the red story and red spirit. The red culture should be seen, felt, and learned everywhere in the university campus, and strengthens the infection of red culture to the ideology of college students. On the other hand, the red culture education should be combined with the students' moral education, the daily standard education and the socialist core values education, and carries out the campus red culture excellent activities with a clear theme and rich layers, to guide students to understand and understand red culture, and to promote red culture education into the brain.

Secondly, innovative forms and means of Red Culture Education.

We should innovate the methods and means of the red culture classroom teaching, overcome the one-way instillation transmission, and use the discussion teaching method, the situational teaching method, the experiential teaching method and the case teaching method to cater to the students' preferences, mobilize the students' subjective initiative, change the passive instillation, and establish an equal and two-way education model. This way enables students to participate in the joyful participation experience, promote the combination of perceptual knowledge and rational knowledge, and enhance the vividness and appeal of classroom teaching. Build the student red education practice platform, encourage students to combine their own professional skills to innovate the red culture to visit and carry forward the means of communication, fully mobilize the initiative of the student party members, to study, think, guide and demonstrate the broad masses of students, so as to achieve the win-win of the integration of Party education and ideological and political education.

Thirdly, broaden the practice of red culture and education.

Persist in combining theory with practice, and guide students party members to transform their ideological and moral cognition into moral behavior. By strengthening the cooperation and exchange with the red tourism base and patriotic education base, the educational functions of the base, such as the revolutionary sites, the memorial halls and the exhibition halls, are fully brought into full play. Regularly organize student party members to visit research, carry out patriotism education and revolutionary traditional education, form a joint effort with the theory teaching in the school, promote the cultivation of the patriotic emotion of the students and the formation of the communist belief.

\section{References}

[1] R.Q. Chen, Innovative use of red culture in college students' ideological and political education work, J. Ideological and Political Education. 4 (2013)

[2] Y.B. Li , Research on the subjectivity of student Party members in the work of Party building in colleges and universities, J. The Party Building and Ideological Education in Schools. 10 (2009).

[3] K. Li, S.F. Li, Red culture: the effective carrier of undergraduate Party member education-- taking Jinggangshan red culture as an example, J. Journal of Lanzhou Institute of Education. 33 (2017)

[4] Y. Rao, B. Tu, Education and training of undergraduate Party members in the context of red culture, J. Journal of Nanchang Vocational \& Technical Teachers' College. 7 (2012).

[5] R.Q. Chen, The innovative application of red culture in the ideological and political education of college students, J. Journal of Jiamusi Vocational Institute. 4 (2013). 